\title{
Conjugation of 1-naphthol in human gastric epithelial cells
}

\author{
P Déchelotte, M Varrentrapp, H J Meyer, M Schwenk
}

\begin{abstract}
The biotransformation of xenobiotics is essential to the maintenance of the body's integrity. Mucosal biotransformation has been well documented in the small and large intestine of animals and humans but whether the gastric mucosa plays a role in detoxifying ingested compounds remains largely unknown. The conjugation of the model phenolic compound, 1-naphthol, by human gastric epithelial cells was assessed in vitro. Freshly isolated and cultured epithelial cells were prepared from surgical specimens obtained from patients undergoing total gastrectomy for cancer. Cell preparations were incubated with 1- ${ }^{14} \mathrm{C}$-naphthol over 1 hour and the glucuronide and sulphate conjugates formed were separated by thin-layer chromatography. Conjugation of 1-naphthol was observed with both freshly isolated and cultured cells. In freshly isolated cells, the 1 hour turnover of $1 \mu M$ 1-naphthol to its glucuronide and sulphate conjugates averaged $19 \%$ and $10 \%$ respectively. At higher 1-naphthol concentrations, both types of conjugate were formed at about the same rate, up to saturation (apparent $\mathrm{V}_{\max }=0.07 \mathrm{nmol} / \mathrm{mg}$ protein $/$ minute, and apparent $\mathrm{Km}=\mathbf{4 0} \mu \mathrm{M}$ ). In cultured cells, the 1 hour turnover of $1 \mu M 1$-naphthol to its glucuronide and sulphate conjugates averaged $35 \%$ and $8 \%$ respectively. These results suggest that the human gastric mucosa is a detoxifying organ, and that its role with regard to chemical carcinogenesis and drug first pass metabolism deserves further assessment. (Gut 1993; 34: 177-180)
\end{abstract}

The organism protects itself from potentially harmful foreign compounds by oxidative and conjugative biotransformation reactions that can occur as early as in the gastrointestinal tract..$^{1-5}$ We eat phenolic compounds daily, in amounts of several hundred $\mathrm{mg}$, as natural plant components (flavonoids, anthocyanes), contaminants or additives (spices, colours, antioxidants), or drugs (oestrogens, paracetamol, salbutamol), and their detoxification is thus of crucial importance.

It has been reported in animals and humans that the mucosa of the small and large intestine is able, to a considerable extent, to detoxicate phenols by conjugation. ${ }^{+13}$ In contrast, the role of the stomach in biotransformation reactions has been considered negligible, probably because some authors failed to detect significant oxidative activity in gastric mucosa,${ }^{14}$ despite the fact that enzymes involved in glucuronidation had earlier been found in the gastric mucosa of rodents..$^{15}$ We recently reported, however, considerable glucuronidation and sulphation activity in the guinea pig gastric epithelium. ${ }^{17}$ This present study provides evidence that human gastric epithelial cells also exert an important conjugative effect on the phenolic compound 1-naphthol.

\section{Methods}

PATIENTS AND CELL PREPARATION

Surgical specimens of gastric mucosa were obtained from 10 patients (aged 42-78 years) who required total gastrectomy for cancer. Adenocarcinomas were located in the antrum in seven patients, in the corpus in two patients, and at the oesogastric junction in one patient. Patients who had previously received antimitotic or enzyme inducing drugs and those with severe atrophic gastritis were excluded.

\section{Cell isolation procedure}

Specimens $\left(4-6 \mathrm{~cm}^{2}\right)$ were taken from a macroscopically healthy part of the corpus region of the freshly removed stomach, at least $8 \mathrm{~cm}$ from the tumour margin, and were placed in ice cold Hank's buffer. Gastric mucosal cells were isolated according to the method described by Soll et al, ${ }^{18}$ modified by Sewing et al, ${ }^{19}$ and adapted for human tissue by Varrentrapp et al. ${ }^{20}$

Briefly, after removing gastric mucus with sterile pads, mucosa from the fundic region was scraped off, suspended in buffer A $(70 \mathrm{mM}$ $\mathrm{NaCl}, 20 \mathrm{mM} \mathrm{NaHCO}, 1.5 \mathrm{mM} \mathrm{Na} \mathrm{HPO}_{4}, 5$ $\mathrm{mM} \mathrm{KCl}, 1.5 \mathrm{mM} \mathrm{MgCl}, 5 \mathrm{mM}$ glucose, and 50 mM HEPES), cut into small pieces, and centrifuged $(5$ minutes at $200 \mathrm{~g}$ ). The pelleted material was resuspended in $40 \mathrm{ml}$ of an isolation medium consisting of buffer A supplemented with $1 \cdot 15$ mg collagenase type I (from Clostridium histolyticum; Sigma Chemical Co, St Louis, MI, USA), and $20 \mathrm{mg}$ collagenase (from $\mathrm{Cl}$ histolyticum; Serva, Heidelberg, Germany). The suspension was preincubated for 10 minutes at $37^{\circ} \mathrm{C}$ and gassed with carbogen while stirring. The $\mathrm{pH}$ was kept at 7.4 by adding a solution of $5 \%$ TRIS. After this 10 minute preincubation, the tissue fragments were pelleted ( 2 minutes at $200 \mathrm{~g}$ ) and incubated in $40 \mathrm{ml}$ of isolation medium supplemented with $10 \mathrm{mg}$ pronase $\mathrm{E}$ (from Streptomyces griseus, Serva), $25 \mathrm{mg}$ hyaluronidase (Sigma), and $0 \cdot 1 \%$ bovine serum albumin. After 30 minutes, the incubation was stopped, cells were filtered through a nylon cloth (mesh width 30 $\mu \mathrm{m}$ ), and were washed three times in buffer A supplemented with $25 \mathrm{mM}$ HEPES and $0 \cdot 1 \%$ bovine serum albumin. The isolated cells were centrifuged $(5$ minutes at $200 \mathrm{~g}$ ). Cell viability was checked by trypan blue exclusion test and cells were used only if viability exceeded $\mathbf{9 0 \%}$. 
Cell suspensions were used either for immediate incubation or cultured.

\section{Cell culture procedure}

The procedure was adapted from that previously used in the guinea pig. ${ }^{21}$ Cells were suspended in sterile culture medium: minimum essential medium (MEM) containing Hank's salts supplemented with $20 \mathrm{mM}$ HEPES, $25 \mathrm{mM} \mathrm{NaHCO}_{3}$, $10 \%$ fetal calf serum (FCS), gentamycin $(5 \mu \mathrm{g} /$ $\mathrm{ml})$, and amphotericin B $(2.5 \mu \mathrm{g} / \mathrm{ml})$. The cell count was estimated in a Türck haemocytometer. About $6 \times 10^{6}$ cells were spread on $6 \mathrm{~cm}$ plastic culture dishes (TC quality, Greiner, Nürtingen, Germany). The dishes were precoated with 300 $\mu$ l of a 1:10 diluted collagen type I solution (Sigma). The dishes were placed in the incubator at $37^{\circ} \mathrm{C}$ in an atmosphere of $5 \% \mathrm{CO}_{2}$ in $100 \%$ humidity. The culture medium was changed daily.

\section{CONJUGATION OF 1-NAPHTHOL BY HUMAN GASTRIC CELLS}

The ability of human gastric mucosa to conjugate phenolic compounds was assessed with the model compound 1-naphthol, which is known to be detoxicated only by conjugation (glucuronidation and sulphation) in varied animal and human tissues. ${ }^{4671017}$

Aliquots of freshly isolated cells (approximately $1 \mathrm{mg}$ total cell protein, about $5 \times 10^{6}$ cells) or 4 day old cultures were incubated in $2 \mathrm{ml}$ $M E M$ at $37^{\circ} \mathrm{C}$. After a 10 minute preincubation period, $1-{ }^{14} \mathrm{C}$-naphthol $(0.5 \mu \mathrm{Ci}, 54 \mathrm{mCi} / \mathrm{mmol}$, Amersham, Braunschweig, Germany) and cold 1-naphthol (Sigma) were added (1-900 $\mu \mathrm{M}$ final concentration). At various times over 1 hour, $200 \mu \mathrm{l}$ samples were taken (three to five samples), without volume replacement. Samples were immediately denaturated with $400 \mu \mathrm{l}$ of a methanol:chloroform (3:1) mixture and shaken for 5 minutes. The extraction was terminated by adding $600 \mu \mathrm{l}$ chloroform, resulting in an aqueous upper phase containing conjugates and an organic lower phase containing unconjugated Data are means from six cell preparations.
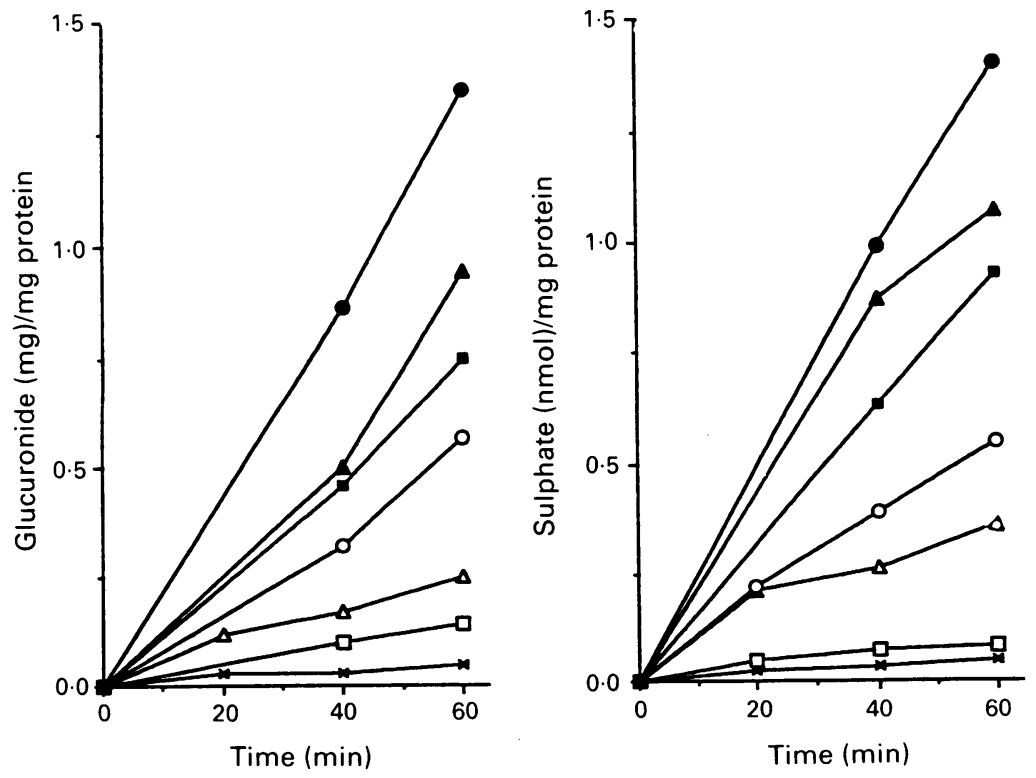

naphthol. Aliquots $(20 \mu \mathrm{l})$ from the resulting aqueous and organic phases were taken and evaporated. After the addition of $2 \mathrm{ml}$ of scintillator, radioactivity was counted in a Hewlett Packard liquid scintillation counter to determine the whole amount of conjugates formed and the remaining unconjugated naphthol. To determine the proportion of each type of conjugate, aliquots $(50 \mu \mathrm{l})$ of the aqueous phase were applied to silica gel thin layer chromatography foils, and 1-naphthol glucuronide was separated from 1-naphthol sulphate in a solvent system consisting of $n$-butanol:0.01 $M$ TRIS:propionic acid $(75: 14: 1 \cdot 1)$. The $R_{f}$ values were 0.26 for 1-naphthol glucuronide and 0.69 for 1-naphthol sulphate. ${ }^{617}$ The radioactive bands were detected in a radioactivity scanner (Rita 90, Raytest, Straubenhardt, Germany) and the peaks integration was performed according to standardised parameters. The protein content of preparations was assayed by a modified Biuret method.

\section{Results}

The phenolic compound 1-naphthol was efficiently conjugated by human gastric epithelial cells in both types of preparations. In freshly isolated cells, the turnover of 1-naphthol into its conjugates over the 60 minutes of incubation averaged $29 \%$ of the added dose at $1 \mu \mathrm{M}$, and $3 \%$ at $100 \mu \mathrm{M}$, with complete saturation when the concentration was increased up to $900 \mu \mathrm{M}$. Both glucuronide and sulphate conjugates were formed at about the same rate (Fig 1). Apparent Michaelis constants, estimated from a Lineweaver-Burk plot, were similar for both reactions: the apparent $\mathrm{V}_{\max }=0.07 \mathrm{nmol} . \mathrm{mg}$ protein $^{-1} \cdot \mathrm{min}^{-1}$, and apparent $\mathrm{Km}=40 \mu \mathrm{M}$.

The 4 day old gastric cell cultures exhibited confluent islets of monolayers, and in some instances there were already confluent monolayers containing mainly mucous cells. ${ }^{20}$ In cell cultures, the turnover of $1 \mu \mathrm{M} 1$-naphthol to its conjugates averaged $43(13) \%$ (mean (SEM)) of the added dose over 60 minutes (Fig 2), with glucuronidation exceeding sulphation.

\section{Discussion}

The rapid conjugation of phenolic compounds in the gastrointestinal tract and the liver has been considered to be a defence mechanism of the organism against intruding toxicants. ${ }^{2+5}$ The phenolic compound 1-naphthol is efficiently absorbed and at the same time more than $90 \%$ is conjugated by the intestine of rodents. ${ }^{+}$ 1-naphthol conjugating activities have also been described in normal and tumourous human colon $^{910}$ and 4-nitrophenol-glucuronosyltransferase activity has been detected at varied levels in all parts of the human small and large intestine. ${ }^{8}$

The present study shows, for the first time, that this defence mechanism is also active in human gastric epithelium. When one considers that the gastric storage times of nutrients ${ }^{22}$ or drugs $^{23}$ may be up to 6 hours or more, the gastric conjugative activity in humans may be relevant to the inactivation of nutritional compounds and therapeutic drugs. 


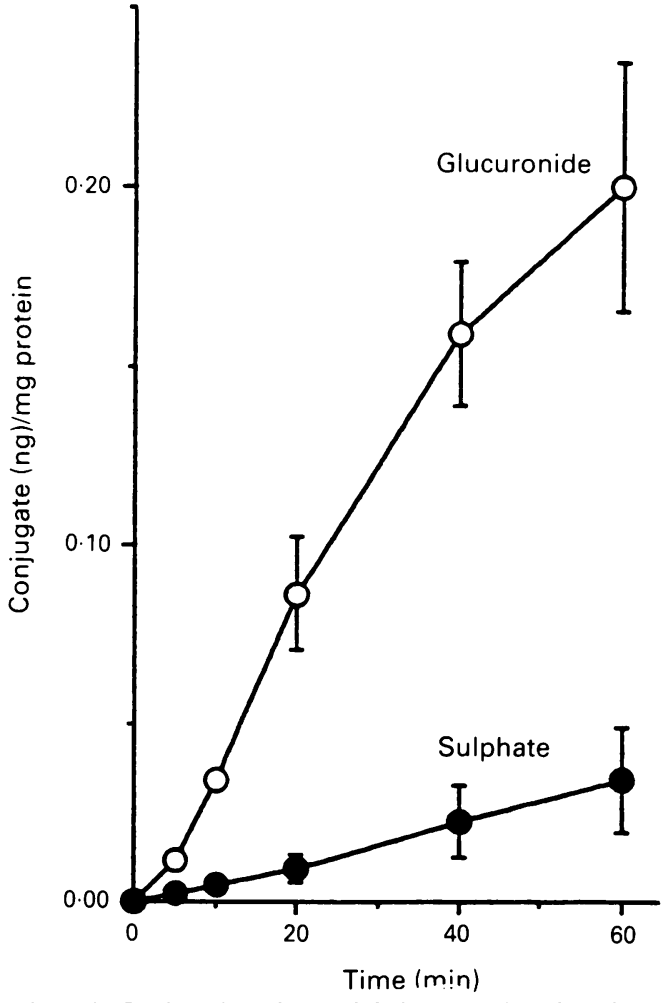

Figure 2: Conjugation of 1-naphthol $(1 \mu M)$ in cultured human gastric epithelial cells. The culture medium of 4 day old cultures was replaced by $2 \mathrm{ml}$ of minimal essential medium and the cultures were incubated at $37^{\circ} \mathrm{C}$ in ambian air with $1 \mu M 1-{ }^{14} C$-naphthol. Samples were taken and processed as in Figure 1. Data are mean values (SEM) from four series of cultures.

The total rate of conjugation of 1-naphthol observed in our experiments with isolated human gastric cells was in the same range as those reported for the large intestine, but somewhat lower. ${ }^{10}$ When $1.5 \mu \mathrm{M}$ 1-naphthol was incubated with isolated human colonic crypts, the turnover rate reached $55 \%$ over 40 minutes, with about $0.25 \mathrm{nmol}$ conjugates $/ \mathrm{mg}$ protein already being formed at 20 minutes. The apparent $\mathrm{V}_{\text {max }}$ derived from additional incubations with human colonic crypts amounted to $0.2 \mathrm{nmol} / \mathrm{mg}$ protein/minute, which is about twice the value estimated from the present data with isolated gastric cells. Similarly, total turnover rates ranging from $50-70 \%$ over 60 minutes were observed when $1 \mu \mathrm{M}$ 1-naphthol was incubated with isolated human enterocytes (unpublished observations). Pacifici et $a l^{24}$ also reported that nuclear and microsomal fractions of human small intestinal mucosa were able to glucuronidate 1-naphthol efficiently but sulphation was not studied by these authors. ${ }^{24}$ In freshly isolated human gastric cells, glucuronidation slightly exceeded sulphation at low naphthol concentrations, but both reactions occurred at about the same velocity at higher concentrations. In contrast, sulphation of 1 to $120 \mu \mathrm{M}$ 1-naphthol always predominated glucuronidation (3:1) in human colonic crypts ${ }^{10}$ as well as in cultured non-tumourous human colon. ${ }^{9}$ Similar differences in glucuronidation/sulphation patterns between the stomach and the colon have been observed in the guinea pig. ${ }^{617}$

In the present experiments with cultured gastric cells, the rates of conjugation, especially of glucuronidation, were higher, on a protein content basis, than in freshly isolated cells. This may be a result of the predominence of mucous cells in cultures, ${ }^{2021}$ as these were the most efficiently conjugating cell type in the guinea pig gastric mucosa. ${ }^{17}$ In addition, upregulation of glucuronidation and downregulation of sulphation after a few days of culture may have a role, as has been observed for 1-naphthol conjugation in cultured human hepatocytes. ${ }^{25}$

The present results illustrate further the suitability of isolated and cultured cells for studying epithelial biotransformation reactions. ${ }^{9102627}$ The procedure used here yielded isolated gastric cells of high viability that could be cultured easily. It would be a significant advance if these suspensions and cultures of gastric cells proved adequate for investigating the effects of nutritional inducers on gastric biotransformation. ${ }^{28} 29$

The stomach has long been forgotten in drug metabolism studies. The finding of considerable gastric drug metabolising activity in the present investigation, confirming our recent animal studies, ${ }^{17}$ should encourage new efforts to determine the role of gastric metabolism not only in early detoxication of ingested chemicals and drugs but also in chemical carcinogenesis. ${ }^{30}$

The skillful technical assistance of Mrs I Hackbarth is gratefully acknowledged. P Déchelotte was supported by the Institu National de la Santé et de la Recherche Médicale, France, and is currently working at the Policlinique - GBPDN, 76031 Rouen Cedex, France.

1 Hartiala K. Metabolism of hormones, drugs and other substances by the gut. Physiol Rev 1973; 53: 496-534

2 Hoensch HP, Schwenk M. Intestinal absorption and metabolism of xenobiotics in humans. In: Schiller CM, ed. Intestinal toxicology. New York: Raven Press, 1984: 169-92.

3 Laitinen M, Watkins JB. Mucosal biotransformation. In: Rozman K, Hänninen O, eds. Gastrointestinal toxicology.

4 Schwenk $M$. Glucuronidation and sulfation in the gastrointestinal tract. Progress in pharmacology and clinical pharmacology Vol 7. Stuttgart: Gustav Fischer Verlag, 1989: macology

5 Powell GM, Miller JJ, Olavesen AH, Curtis CG. Liver as major organ of phenol detoxication? Nature 1974; 252: 234-5

6 Schwenk M, Locher M. 1-Naphthol conjugation in isolated cells from liver, jejunum, ileum, colon and kidney of the guinea pig. Biochem Pharmacol 1985; 34: 697-701.

7 Koster AS, Frankhuijzen-Sierevogel AC, Noordhoek J. Distribution of glucuronidation capacity (1-Naphthol and morphine) along the rat intestine. Biochem Pharmacol 1985 ; 34: 3527-32.

8 Peters WHM, Kock L, Nagengast FM, Kremers PG. Biotransformation enzymes in human intestine: critical low transformation enzymes in human intest

9 Gibby EM, Cohen GM. Conjugation of 1-naphthol by human colon and tumour tissue using different experimental systems. Br f Cancer 1984; 49: 645-51.

10 Schwenk M. Glucuronide conjugation in isolated cells from intestine, liver and kidney. In: Matern S, Bock KW, Gerok W, eds. Advances in glucuronide conjugation. Lancaster: MTP Press, 1985: 165-75.

11 Ramakrishna BS, Roberts-Thomson IC, Pannall PR, Roediger WEW. Impaired sulphation of phenol by the colonic mucosa in quiescent and active ulcerative colitis. Gut 1991; 32: 46-9.

12 Déchelotte $P$, Schwenk $M$. Conjugation of phenols in human colonocytes [letter]. Gut 1991; 32: 963.

13 Rogers SM, Back DJ. The use of Ussing chambers for the study of intestinal metabolism in vitro. In: Koster $\mathrm{A} \mathrm{Si}$ Richter E, Lauterbach F, Hartmann F, eds. Intestinal metabolism of xenobiotics. Stuttgart: Gustav Fischer Verlag, metabolism of

14 Wattenberg LW, Leong JL, Strand PJ. Benzpyrene hydroxy lase activity in the gastrointestinal tract. Cancer Res 1962: 22 $1120-5$

15 Hänninen O, Aitio A, Hartiala K. Gastrointestinal distribution of glucuronide synthesis and the relevant enzymes in the rat. Scand $\mathcal{F}$ Gastroenterol 1968; 3: 461-4.

16 Aitio A, Hietanen E, Hänninen $O$. Mucosal drug metabolism and drug-induced ulcer. In: Gheorghiu T, ed. Experimental ulcer. Baden-Baden: G Witzstrock, 1975: 17-21.

17 Schwenk M, Linz C, Kobusch AB. Conjugation of 1-naphtho in the gastric mucosa of guinea pigs. Biochem Pharmacol 1991; 42: 469-73.

18 Soll AH. The action of secretagogues on oxygen uptake by isolated mammalian parietal cells. $\mathcal{F}$ Clin Invest 1978; 61: 370-80.

19 Sewing K Fr, Harms P, Schuly G, Hanneman H. Effect of substituted benzimidazoles on acid secretion in isolated and substituted benzimidazoles on acid secretion in isolated a 
20 Varrentrapp M, Giebel J. Wagner S, Meyer HJ, Neumann C, Schwenk M. Primärkultur humaner MagenschleimhautSchwenk M. Primärkultur humaner Magenschleimhaut-
zellen zur Untersuchung zellpathologischer Wirkungen von zellen zur Untersuchung zellpathologischer Wirkungen von
Helicobacter pylori. [Abstract.] Z Gastroenterol 1991; 29: 510 .

21 Schwenk M, Giebel J, Thiedemann KU. Self-organization of gastric mucosal cells in culture. In: Halter F, Garner A Tytgat GN, eds. Mechanisms of peptic ulcer healing. Dordrecht: Kluwer Academic Publishers, 1991: 91-101.

22 Hunt JN, Know MT. Regulation of gastric emptying. In: Code CF, ed. Handbook of physiology. The alimentary canal. Vol IV: Motility. Washington: American Physiology Society, 1967: 1917-36.

23 Davis SS, Hardy JG, Fara JW. Transit of pharmaceutical dosage forms through the small intestine. Gut 1986; 27: dosage

24 Pacifici GM, Giulani L, Calcaprina R. Glucuronidation of l-naphthol in nuclear and microsomal fractions of the human intestine. Pharmacology 1986; 33: 103-9.

25 Grant MH, Burke MD, Hawksworth GM,Duthie SJ, Engese $\mathrm{J}$, Petrie JC. Human adult hepatocytes in primary monolayer culture. Maintenance of mixed function oxidase and conjugation pathways of drug metabolism. Biochem Pharmacol 1987; 36: 2311-6.

26 Dawson JR, Schwenk M. Isolated epithelial cells. In: Koster A Si, Richter E, Lauterbach F, Hartmann F, eds. Intestinal metabolism of xenobiotics. Stuttgart: Gustav Fischer Verlag, 1989: $21-41$

27 Déchelotte $P$, Schwenk $M$. In vitro studies with colonic tissue and isolated cells. In: Bieck PR, ed. Colonic drug absorption and metabolism. New York: Marcel Dekker (in press)

28 Schepp W, Miederer SE, Ruoff HJ, Wulfhekel U. Isolierte menschliche Magenschleimhautzellen-Untersuchungen physiologischer und pharmakologischer Regulationsphysiologischer und pharmakologischer
mechanismen. Klin Wochenschr 1986; 64: 15-22.

29 Forster U, Luippold G,Schwarz LR. Induction of monooxygenase and UDP-glucuronosyltransferase activities in primary cultures of rat hepatocytes. Drug Metabol Dispos 1986; 14: 353-60.

30 Triolo AJ, Aponte GE, Herr HR. Induction of aryl hydrocarbon hydroxylase and forestomach tumors by benzo(a)pyrene. Cancer Res 1977; 37: 3018-21. 